\title{
A Numerical Experiment on Sea Surface Temperature Anomalies and Warm Winter in Japan
}

\author{
By Akio Kitoh \\ Meteorological Research Institute, Tsukuba, Ibaraki 305, Japan \\ (Manuscript received 25 March 1988, in revised form 18 June 1988)
}

\begin{abstract}
Impact of the sea surface temperature anomalies (SSTAs) on atmospheric circulations are studied with emphasis on the winter climate in Japan with the use of an atmospheric general circulation model.

The empirical orthogonal function analyses are performed for precipitation, geopotential height at $500 \mathrm{mb}$ and surface air temperature. It is shown that leading eigenvectors of precipitation are zonally elongated in the tropics and that the distribution of positive and negative precipitation anomalies is dependent on the SST and precipitation field in the control run. Surface air temperature in East Asia is mostly governed by the temperature contrast between Japan-East China region and the Sea of Okhotsk. This is associated with high pressure anomalies in the North Pacific Ocean, which weakens the cold surge from Siberia. This circulation is found in the first eigenvector in the present experiment $\mathrm{El}(\mathrm{Z500})$ and is dominant in the run which uses the composited January SSTA observed during warm winter in Japan. The simulated anomalies in mid-latitude circulation correspond well with the observations.

An additional run with the SSTA over the equator east of the dateline gives the largest anticyclonic circulation response over the North Pacific Ocean and the warmest surface air temperature anomalies in East Asia. The pattern relevant to warm winter in Japan is not a simple atmospheric response to tropical heating. It is conceivable that inherently there is a dominant circulation mode like El(Z500) and that this mode can be activated either by a direct and/or an indirect orographic effect or by anomalous heating induced by the SSTA. This pattern can be understood as a response to subtropical mass source/sink distribution under the framework of a linear theory.
\end{abstract}

\section{Introduction}

Numerical experiments to study atmospheric responses to the sea surface temperature anomalies (SSTAs) were commenced by Rowntree (1972), being inspired by the pioneering work of Bjerknes $(1966,1969)$. It is followed by Julian and Chervin (1978), Shukla and Wallace (1983), Blackmon et al. (1983), Geisler et al. (1985) and Tokioka et al. (1986a) among others. In particular since the big 1982/83 El Niño, much attention is paid to El Niño and its influence on the atmosphere, and many experiments using the observed 1982/83 El Niño SSTA or an idealized SSTA were performed and

(C) 1988, Meteorological Society of Japan intercomparison of model results is made (Nihoul, 1985; WCP, 1986).

The interannual variation of the interaction between the tropics and mid-latitudes during the northern winter has been investigated associated with the El Niño/Southern Oscillation phenomena (e.g., Horel and Wallace, 1981; van Loon and Rogers, 1981; Lau and Chan, 1983a, b). Keshavamurty (1982) performed sensitivity experiments with warm idealized SSTAs over the eastern, central and western equatorial Pacific Ocean during northern summer season with the GFDL GCM and obtained a larger atmospheric response in case of the central and western Pacific anomalies. Simmons et al. (1983) and Branstator (1985) show that the winter atmos- 
phere is most sensitive to the forcing over the Southeast Asia/Indochina region. A review of the studies of SSTAs and atmospheric circulations in mid-latitudes can be found in Frankignoul (1985).

As to the direct relation between winter climate in Japan and the global SSTAs, several groups have undertaken an analysis of the observational data (e.g., Kawamura, 1984, 1986; Iwasaka et al., 1987). The winter climate in Japan tends to be mild in El Niño years. That was true in $1982 / 83$ and $1986 / 87$ winter, but not in the 1976/77 winter. The surface air temperature in central Japan is shown to have high temporal correlation with warm SSTA over the equatorial central Pacific Ocean, but also with warm SSTA over south and east off Japan, the South China Sea and the Indian Ocean. On the other hand it is reported that SSTA in the North Pacific Ocean is caused by an atmospheric fluctuation (Kawamura, 1984; Iwasaka et al., 1987). Kawamura (1984) claims that warm SSTA off Japan is a result of the weaker cold surge than normal.

The purpose of this experiment is to study whether the SSTA observed in a "warm year" in Japan can produce circulation anomalies relevant to warm Japan, and, if so, to study which SSTA mostly affect those circulation anomalies. Section 2 shows the relation between winter climate in Japan and the SSTA. Section 3 describes the model used and the design of the experiment. The model climate in the control run is briefly shown in Section 4. Characteristics of low-latitude precipitation are studied in Section 5. and mid-latitude circulation variability is examined in terms of geopotential height at $500 \mathrm{mb}$ in Section 6. Discussions are presented in Section 7 and conclusions are made in Section 8.

\section{Winter temperature in Japan and global sea surface temperature}

\section{a. Surface air temperature in Japan}

In order to define years of warm/cold winter in Japan, areal mean surface air temperature in Japan is calculated from twelve climatological observation stations* from 1970 to 1984 (Japan

\footnotetext{
* Sapporo, Nemuro, Akita, Miyako, Wajima, Matsumoto, Yonago, Shionomisaki, Fukuoka, Kagoshima, Shimizu (Ashizuri) and Ishigakijima.
}

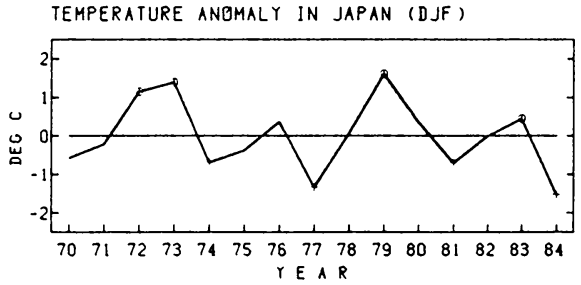

Fig. 1. December-January-February surface air temperature anomalies in Japan calculated from 12 climatological observation stations from 1970 to 1984.

Meteorological Agency, 1980, 1981, 1984, 1987). Here 'winter' is defined as December, January and February, and the year of 1970 represents a mean of December 1969, January 1970 and February 1970. Figure 1 shows the winter temperature anomaly from the 15-year mean. The four warm winters in Japan in the upper quartile of this distribution include 1979, 1973, 1972 and 1983 (in the descending order of temperature anomaly). The four cold winters in Japan of this distribution include 1984, 1977, 1981 and 1974 (in the ascending order). The El Niño years in this period are 1970, 1973, 1977 and 1983 (Rasmusson and Carpenter, 1982; Weare, 1986). Among these four years, two years and one year are selected as warm and cold years in Japan, respectively.
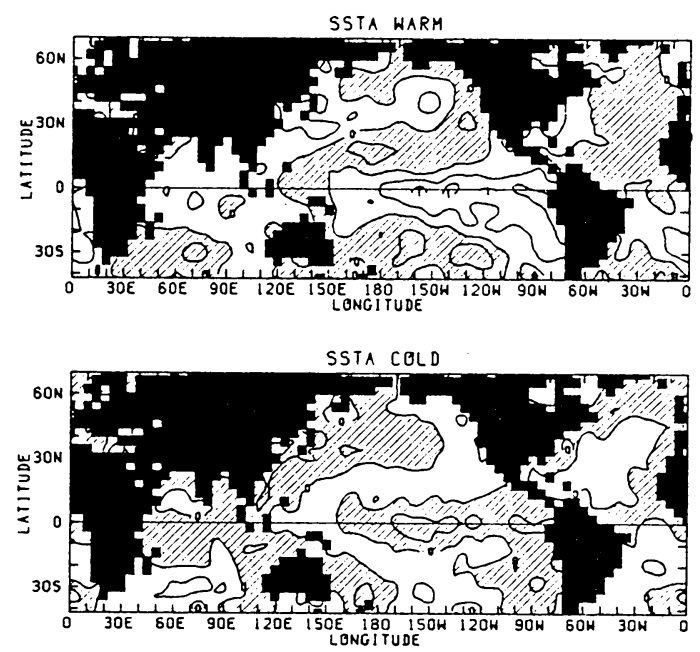

Fig. 2. The composited January sea surface temperature of 1972, 1973, 1979 and 1983 (top) and of 1974, 1977, 1981 and 1984 (bottom). Contour interval is $0.5^{\circ} \mathrm{C}$. Negative values are shaded. 


\section{b. Sea surface temperature composite}

Here the SST averaged for four warm and four cold winters in Japan are compared with the normal SST. The SST data edited by U. S. NOAA north of $40^{\circ} \mathrm{S}$ from 1970 to 1984 is used and the 15-year mean is defined as the normal SST in the present experiment.

Figure 2 (top) shows the composited SSTA in four Januarys when the surface air temperature in Japan is warm. The SSTA is characterized by a warmer than normal SST in the central and the eastern equatorial Pacific Ocean surrounded by a horseshoe-shaped colder SST in the subtropics. In the western Pacific Ocean, it is warm to the south and east of Japan, in the South China Sea and to the northwest of Australia, while it is cool to the east of the Philippines. It is also warm in the tropical Indian Ocean. In the Atlantic Ocean it is warm in the southen hemisphere and is cold in the northern hemisphere. Among four years used to compose this SSTA, two years (1973 and 1983) are El Niño years and the composited SSTA in the tropical Pacific Ocean still shows the characteristic pattern of $\mathrm{El}$ Niño, although its magnitude is smaller than the El Niño composite of Rasmusson and Carpenter (1982).

Figure 2 (bottom) shows the composited SSTA in four Januarys when the surface air temperature in Japan is cold. The pattern in Fig. 2 (bottom) is similar to that in Fig. 2 (top) if the sign is reversed in broad regions in the Pacific and the Indian Ocean.

\section{Outline of the model and the design of the experiment}

\section{a. Model}

The model used is the Meteorological Research Institute GCM (MRI-GCM-I) with a horizontal resolution of $5^{\circ}$ in longitude and $4^{\circ}$ in latitude. In the computation of radiative heating rate, the model uses Katayama's parameterization (1972). Predicted amount of water vapor and cloud are used in the computation. The dry convective adjustment, middle level convection and penetrative cumulus parameterization by Arakawa and Schubert (1974) are used for parameterizing convective processes as well as the grid-scale condensation due to supersaturation. Surface fluxes of sensible heat, water vapor and momentum are computed by the bulk method with the transfer coefficient proposed by Deardorff (1972). Ground temperature, snow mass and soil moisture (ground wetness) are predicted by considering ground thermodynamics and hydrology after Katayama (1978). Further details of the model are described in Tokioka et al. (1984). The January performances of the model are reported by Tokioka et al. (1985).

\section{b. Experiment}

The control run (C) started from the NMC analysis of $12 \mathrm{Z} 15$ December 1982 and was integrated for one month to 15 January under the seasonal cycle. Then the seasonal march was stopped and the integration was performed for 180 days under the perpetual January condition. The normal SST is used in C.

Eight anomaly runs were performed for 180 days from 15 January of the control run with the SSTAs as summarized in Table 1. Run AW used the composited SSTA (Fig. 2a) for warm winter in Japan, while run AC used the composited SSTA (Fig. 2b) for cold winter in Japan. Runs A1 through A6 were performed mainly to increase the sample size, although their SSTA regions correspond to key regions in AW. They adopted an idealized rectangular SSTA with its maximum of $1.0^{\circ} \mathrm{C}$ (Fig. 3), which have the positive SSTA over the south maritime continent, the north maritime continent, the Indian Ocean, south of Japan, the central equatorial Pacific Ocean and the negative SSTA east of the Philippines, respectively.

By discarding the first 30 days' data, the remaining 150 days' data in each run were used in the following analyses. For the purpose of empirical orthogonal function (EOF) analyses, 150 days were divided into five 30-day subperiods.

An additional run A7 was also performed with the positive SSTA to the east of the dateline over the equator. This run is not included in the EOF analyses and is independently treated in Section 7.

\section{Control run}

Before discussing the results obtained in this 
Table 1. Summary of numerical simulations

\begin{tabular}{ll}
\hline Run C & 15-year mean SST from 1970 to 1984 \\
Run AW & composited SST of Januarys in $1972,1973,1979$ and 1983 \\
Run AC & composited SST of Januarys in $1974,1977,1981$ and 1984 \\
Run A1 & positive SSTA in $105^{\circ} \mathrm{E}-130^{\circ} \mathrm{E}, 14^{\circ} \mathrm{S}-2^{\circ} \mathrm{S}$ \\
Run A2 & positive SSTA in $105^{\circ} \mathrm{E}-130^{\circ} \mathrm{E}, 2^{\circ} \mathrm{N}-14^{\circ} \mathrm{N}$ \\
Run A3 & positive SSTA in $55^{\circ} \mathrm{E}-80^{\circ} \mathrm{E}, 14^{\circ} \mathrm{S}-2^{\circ} \mathrm{S}$ \\
Run A4 & positive SSTA in $125^{\circ} \mathrm{E}-150^{\circ} \mathrm{E}, 18^{\circ} \mathrm{N}-30^{\circ} \mathrm{N}$ \\
Run A5 & positive SSTA in $165^{\circ} \mathrm{E}-170^{\circ} \mathrm{W}, 14^{\circ} \mathrm{S}-2^{\circ} \mathrm{S}$ \\
Run A6 & negative SSTA in $125^{\circ} \mathrm{E}-150^{\circ} \mathrm{E}, 2^{\circ} \mathrm{N}-14^{\circ} \mathrm{N}$ \\
Run A7 & positive SSTA in $180^{\circ} \mathrm{W}-155^{\circ} \mathrm{W}, 6^{\circ} \mathrm{S}-6^{\circ} \mathrm{N}$ \\
\hline N & ensemble average of above 9 cases excluding run A7 \\
\hline
\end{tabular}

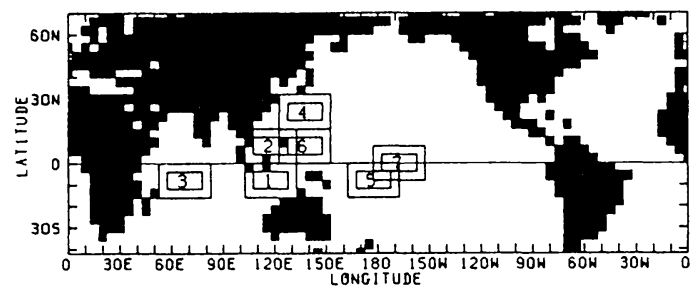

Fig. 3. Sea surface temperature anomalies used in runs A1 through A7. Magnitude is $0.5^{\circ} \mathrm{C}$ in a large rectangle and $1.0^{\circ} \mathrm{C}$ in a small rectangle. The sign of SSTA is negative in A6 and positive in the rest.

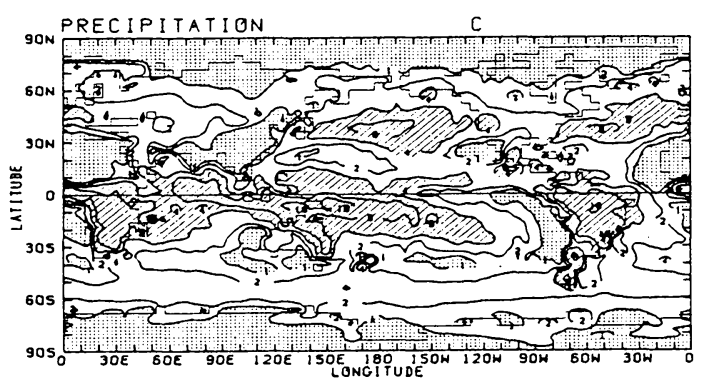

Fig. 4. The precipitation rate in the control run averaged for 150 days. Contours of $1,2,4,8$ and 16 $\mathrm{mm} \mathrm{d}^{-1}$ are drawn. Values greater than $4 \mathrm{~mm} \mathrm{~d}^{-1}$ are shaded and those less than $1 \mathrm{~mm} \mathrm{~d}^{-1}$ are stippled.

experiment, a brief look is made into the model climate in the control run.

Figure 4 shows the horizontal distribution of the 150-day mean precipitation rate in $\mathrm{C}$. Well-organized precipitation areas are found in the tropics except over the eastern oceans where the SST is low. Heavy precipitation greater than $8 \mathrm{~mm} \mathrm{~d}^{-1}$ is simulated over the zonally elongated belt in the south of the equator with its center in the maritime continent, which extends toward the South Pacific Convergence Zone (SPCZ). There is also large precipitation over land in the tropics, i.e., over southern Africa and Brazil. Also found are large precipitation areas over the North Pacific and Atlantic Oceans, which correspond to cyclonically active areas. The control run has produced fairly well the basic climatological characteristics in the precipitation field in this season such as reported by Schutz and Gates (1971).

Overall circulation patterns in the control run also compare favorably with the climatological ones (not shown) and are close to those in Tokioka et al. (1985). For example, a subtropical jet at $300 \mathrm{mb}$ with the zonal velocity greater than $70 \mathrm{~m} \mathrm{~s}^{-1}$ is simulated to the southeast of Japan. That over the east coast of North America has a speed of about $45 \mathrm{~m} \mathrm{~s}^{-1}$. Mid-oceanic troughs are present over the Pacific and Atlantic Oceans in both hemispheres. At the equator, westerlies are found over the eastern Pacific Ocean and over the Atlantic Ocean.

\section{Precipitation in low latitudes}

\section{a. Local response}

Figure 5 shows the 150-day mean precipitation anomaly (AW-C, AC-C, Al-C, ..., A6-C). Anomalies in precipitation and evaporation in $\mathrm{Al}$ through A6 averaged over the corresponding anomaly region are shown in columns 4 and 5 of Table 2 together with the SST and precipitation in C. Response of precipitation over the anomaly region is large in $\mathrm{A} 5$ and $\mathrm{A} 1$. That in $\mathrm{A} 3$ and $\mathrm{A} 2$ 

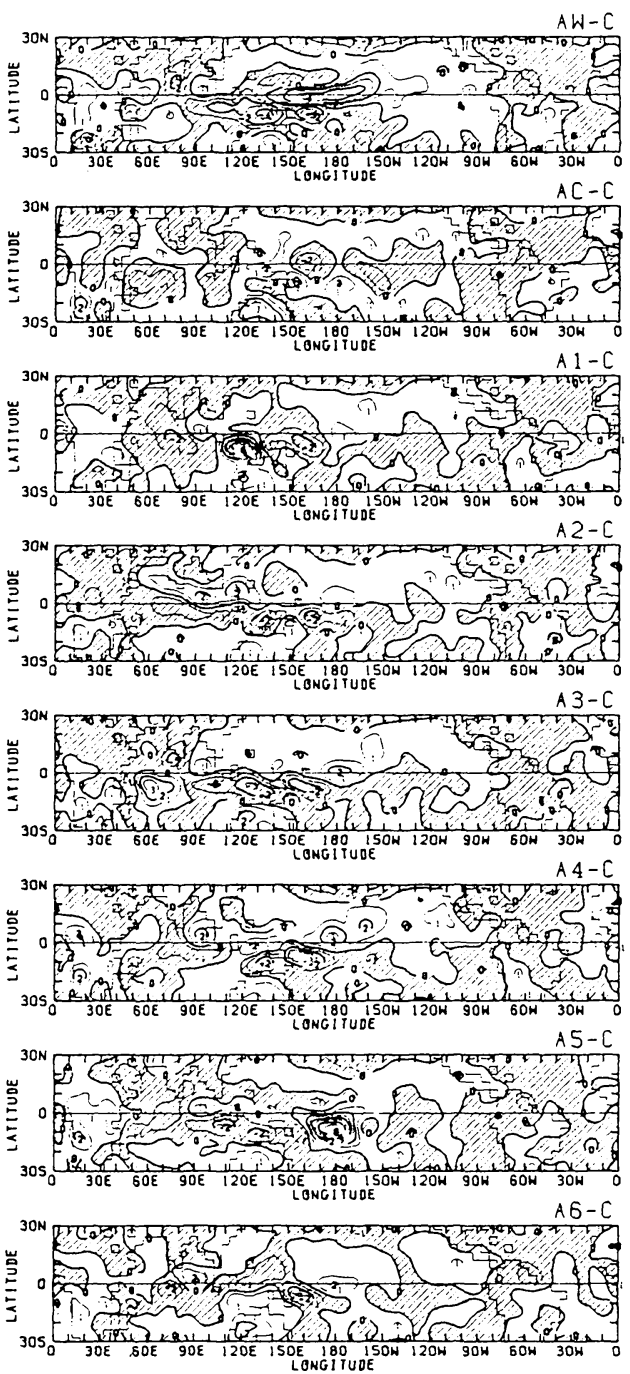

Fig. 5. The 150-day mean precipitation anomaly. Contour interval is $1 \mathrm{~mm} \mathrm{~d}$. Negative values are shaded. is moderate, while that in A4 is small. The largest response of a local precipitation anomaly is obtained where the normal SST is above $28.5^{\circ} \mathrm{C}$ and the precipitation in $\mathrm{C}$ is great. Thus response to the SSTA is not spatially uniform, but is large where there is lots of precipitation in the control run and the low-level circulation is such that the moisture flux convergence maintains the large precipitation. As shown in Table 2, the contribution of the increased local evaporation has a minor role in the increase of precipitation. The increase in precipitation is largely due to the increased moisture flux convergence induced by the circulation change. This is in agreement with the earlier studies (e.g., Cornejo-Garrido and Stone, 1977; Julian and Chervin, 1978; Shukla and Wallace, 1983; Mechoso et al., 1987).

In $\mathrm{A} 2$ and $\mathrm{A} 4$, the evaporation even decreases in spite of the increased local SST. The weakened cold surge gives rise to this result.

\section{b. EOF analysis}

As shown in the previous subsection, a contribution by the increase in local evaporation is generally less than that by moisture flux convergence, although the relative importance of anomalous evaporation and moisture flux convergence in maintaining anomalous precipitation varies in space (Mechoso et al., 1987). When there is an anomalous increase in precipitation which originates from the prescribed SSTA, or whatever the reason, it is accompanied by an anomalous decrease in precipitation caused by moisture flux divergence. In this subsection the characteristic pattern of anomalous precipitation distribution resulting from this SSTA experiment under the perpetual January condition is

Table 2 Sea surface temperature and precipitation for $\mathrm{C}$ averaged over the six SSTA region, and anomalies in precipitation and evaporation in six runs $A 1$ through $A 6$ averaged in their SSTA region.

\begin{tabular}{|c|c|c|c|c|c|}
\hline Region & $\mathrm{SST}$ in $\mathrm{C}$ & $\begin{array}{l}\text { precipitation } \\
\text { in C }\end{array}$ & $\begin{array}{l}\text { precipitation } \\
\text { anomaly }\end{array}$ & $\begin{array}{l}\text { evaporation } \\
\text { anomaly }\end{array}$ & \\
\hline 1 & $28.7^{\circ} \mathrm{C}$ & $9.55 \mathrm{~mm} \mathrm{~d}^{-1}$ & $+3.89 \mathrm{~mm} \mathrm{~d}^{-1}$ & $+0.92 \mathrm{~mm} \mathrm{~d}^{-1}$ & $(\mathrm{~A} 1-\mathrm{C})$ \\
\hline 2 & 27.1 & 3.69 & +1.87 & -0.02 & $(A 2-C)$ \\
\hline 3 & 28.0 & 5.42 & +2.26 & +0.49 & $(A 3-C)$ \\
\hline 4 & 23.0 & 1.96 & +0.45 & -0.29 & $(\mathrm{~A} 4-\mathrm{C})$ \\
\hline 5 & 28.9 & 9.21 & +4.82 & +1.34 & (A5-C) \\
\hline 6 & 28.2 & 4.59 & -1.05 & -0.37 & $(\mathrm{~A} 6-\mathrm{C})$ \\
\hline
\end{tabular}



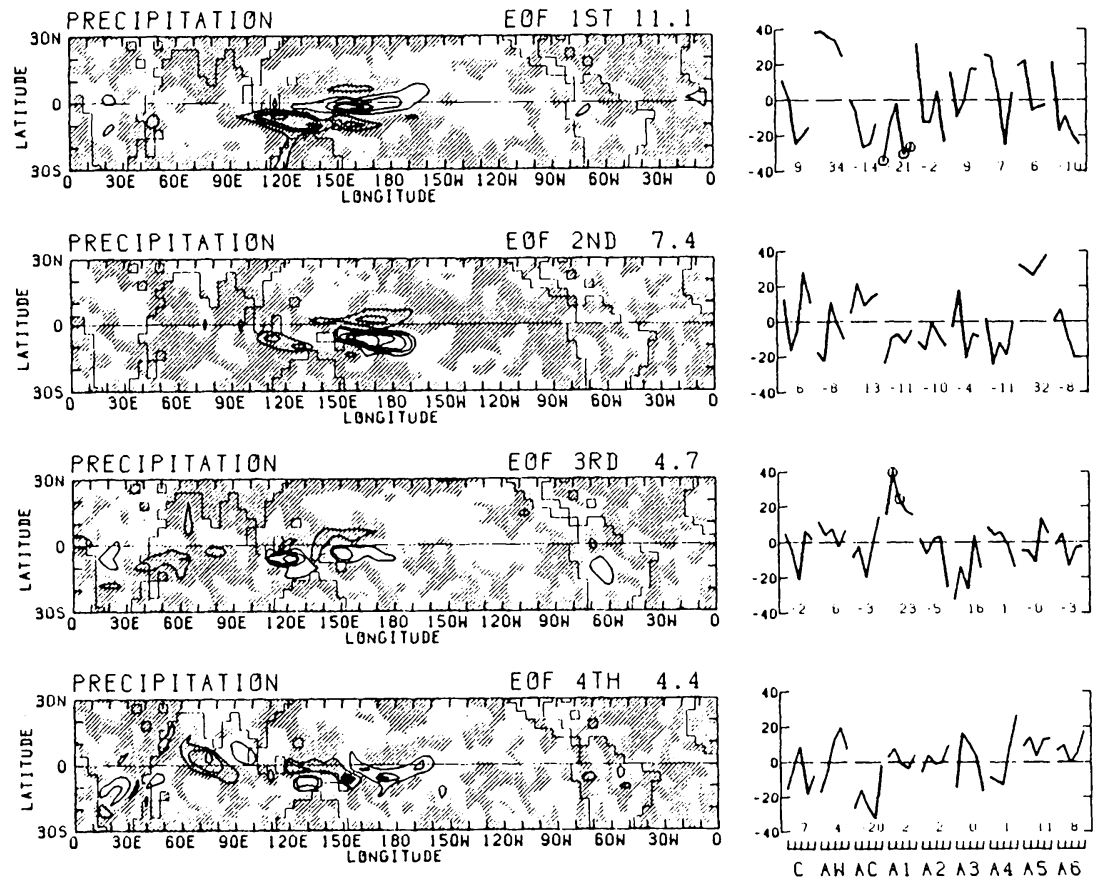

Fig. 6. The leading four eigenvectors (left) and eigencoefficients (right) obtained for precipitation between $30^{\circ} \mathrm{S}$ and $30^{\circ} \mathrm{N}$. Contour interval is 0.04 . Negative values are shaded.

investigated by the EOF analysis using the covariance method.

The precipitation data used is the 30-day averaged precipitation on all grid points between $30^{\circ} \mathrm{S}$ and $30^{\circ} \mathrm{N}$. The 150 days' data in each run is divided into five successive 30 days' data. Therefore, at each grid point, there are 45 data from one control and eight anomaly runs.* The first four eigenvectors and eigencoefficients are shown in Fig. 6.

Firstly the zonally elongated precipitation pattern is noted in low latitudes. A similar structure can be seen in a precipitation pattern map for the Pacific Ocean which is associated with the El Niño/Southern Oscillation (Ropelewski and Halpert, 1987).

* To check the stability of the result, the EOF analysis is repeated by reducing grid points by narrowing the region from $0^{\circ}-360^{\circ}, 30^{\circ} \mathrm{S}-30^{\circ} \mathrm{N}$ to $0^{\circ}-360^{\circ}, 14^{\circ} \mathrm{S}$ $14^{\circ} \mathrm{N}$, and again to $30^{\circ} \mathrm{E}-150^{\circ} \mathrm{W}, 14^{\circ} \mathrm{S}-14^{\circ} \mathrm{N}$. The leading eigenvectors hardly change over the region discussed here, except that the third and fourth eigenvectors obtained in two broader regions appear in the fourth and third eigenvectors in the other, respectively.
The first eigenvector (denoted as El) of precipitation $(\mathrm{Pr}), \mathrm{El}(\mathrm{Pr})$, explains $11.1 \%$ of the total variance. It is characterized by the precipitation anomaly zonally elongated over the equator north of New Guinea. It stretches more than $60^{\circ}$ wide from Borneo to the east of the dateline, although its meridional scale is about $8^{\circ}$ (2 grids in the model). This region is accompanied with other zonally elongated anomaly regions with opposite sign on both sides. The maximum is located over oceans between Indonesia and Australia $\left(120^{\circ} \mathrm{E}, 6^{\circ} \mathrm{S}\right)$, which is contrasted with a center at $150^{\circ} \mathrm{E}, 2^{\circ} \mathrm{S}$. It is noted that the precipitation anomalies in $\mathrm{E} 1$ (Pr) show not a small anomaly northeastward from $0^{\circ} \mathrm{N}, 180^{\circ} \mathrm{E}$ to $16^{\circ} \mathrm{N}, 160^{\circ} \mathrm{W}$.

Overall response in the southern hemisphere is larger than that in the northern hemisphere. Since the present experiment is performed under the perpetual January condition, the SST in the control run is higher in the southern hemisphere than in the northern hemisphere and the precipitation is also larger in the southern hemisphere. It is inferred that meridional 
asymmetry in the precipitation variability is due to this experimental condition.

The coefficient of $\mathrm{El}(\mathrm{Pr})$, denoted as $\mathrm{Cl}(\mathrm{Pr})$, shows that $\mathrm{AW}, \mathrm{Al}$ and $\mathrm{AC}$ are the main contributors to $\mathrm{El}(\mathrm{Pr})$. AW has consistently large coefficients in all five subperiods. On the other hand, $\mathrm{Al}$ and $\mathrm{AC}$ have negative values of coefficients, indicating large positive precipitation anomalies between Indonesia and Australia accompanied by negative ones over the equator to the northeast of the positive anomalies.

E2 $(\mathrm{Pr})(7.4 \%)$ is mainly explained by A5. When there are positive precipitation anomalies to the east of New Guinea, the counteracting negative anomalies appear in a zonally elongated band to the north of it and over the maritime continent to the west of New Guinea. AC, Al and A4 have moderate contributions to this mode.

$\mathrm{A} 1$ and A3 have mostly contributed to E3 (Pr) $(4.7 \%)$. When precipitation in the south maritime continent is large, there are positive anomalies south of the equator and negative anomalies north of the equator between $120^{\circ} \mathrm{E}$ and $180^{\circ} \mathrm{E}$. At the same time there are large negative anomalies in the western Indian Ocean. This anomaly is paired with the anomaly of opposite sign in Central Africa.

The fourth component (E4 (Pr), 4.4\%) has a smaller spatial scale of anomalies than the preceding three EOFs. E4 (Pr) is characterized by chains of positive and negative anomalies in equatorial latitudes in the eastern hemisphere from Africa to the dateline. The coefficients of $\mathrm{AC}$ show large negative values in four out of five subperiods.

It is indicated that $\mathbf{A} 1$, in which the positive SSTA is assigned over the south maritime continent, shows large contributions both in El (Pr) and E3 (Pr). Figure 6 shows that the magnitude of $\mathrm{Cl}(\mathrm{Pr})$ is large in subperiods 1,4 and 5 of $\mathrm{Al}$, and that of $\mathrm{C} 3(\mathrm{Pr})$ is large in subperiods 2 and 3 of $\mathrm{Al}$, as marked by open circles. In the 150-day mean precipitation anomaly map (Fig. 5), positive precipitation anomalies over the SSTA region are flanked with two negative anomalies on the eastern and western sides. Clear distinction into two subperiods (1-4-5) and (2-3) of the eigencoefficients of $\mathrm{Al}$ suggests that the eastern and western pairs of precipitation anomalies occurred independently, resulting in one positive and two negative anomalies in the long-term mean. These precipitation anomalies are accompanied by an east-west circulation. This east-west cell, with its center over the maritime continent and its width of about $60^{\circ}$, can exist on both sides. However, these two east-west cells do not appear simultaneously, but either cell appears at one time.

\section{Mid-latitude circulation}

\section{a. Geopotential height}

The 30-day averaged grid data of geopotential height at $500 \mathrm{mb}(\mathrm{Z} 500)$ are transformed into spherical harmonic functions which have a zonal wavenumber up to 8 and meridional nodes up to 13 as in Tokioka et al. (1986a). The EOF analysis is applied for this time series data of truncated modes. Figure 7 shows the first and second eigenvectors of Z500. El (Z500) explains $33.8 \%$ of the total variance and is characterized by the high pressure region (if a coefficient is positive) over the North Pacific Ocean and the low pressure region over northern Siberia. The former has a center at $165^{\circ} \mathrm{W}, 42^{\circ} \mathrm{N}$, but extends toward Japan. Zonally symmetric anomalies are also noted.

Figure 7 also shows $\mathrm{Cl}$ (Z500). By looking at individual 30-day subperiods, large coefficients are scattered in different runs. For example, the first six largest $\mathrm{Cl}(\mathrm{Z} 500)$ are found in separate runs. But $\mathrm{AW}$ has consistently positive coefficients and the mean coefficient becomes the largest (a mean of the coefficients of five subperiods, C1M, is 26). Therefore a high pressure anomaly in the North Pacific Ocean is the strongest. A4 $(\mathrm{C} 1 \mathrm{M}=19)$ and A3 $(\mathrm{C} 1 \mathrm{M}=9)$ follows that. On the other hand, a low pressure anomaly is strong in $\mathrm{C}(\mathrm{C} 1 \mathrm{M}=-20), \mathrm{A} 6(\mathrm{C} 1 \mathrm{M}=$ $-14)$ and $\mathrm{AC}(\mathrm{C} 1 \mathrm{M}=-10)$ in the 150-day mean.

E2 (Z500) explains $13.4 \%$ of the total variance and is characterized by eddies in northern high latitudes around North America. This pattern corresponds to the intensity of the Aleutian low. C2M is the largest in A5 and the smallest in A2. 

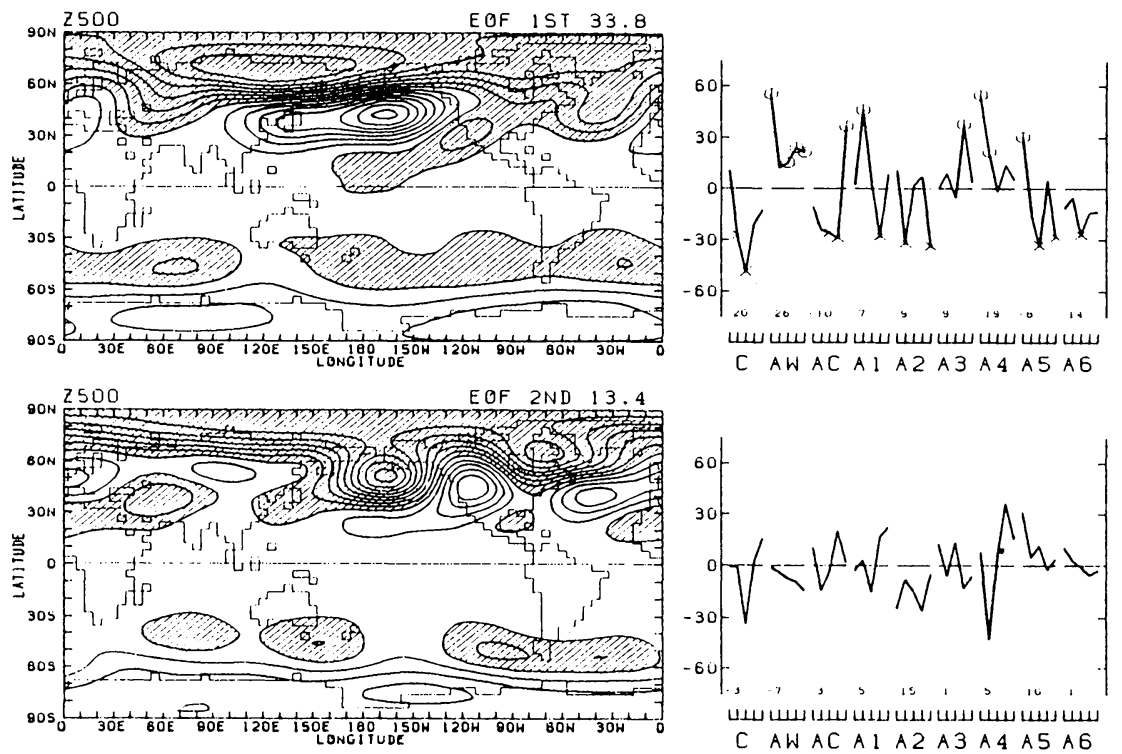

Fig. 7. The first (top) and second (bottom) eigenvectors and their coefficients for geopotential height at $500 \mathrm{mb}$. Contour interval is 0.5 . Negative values are shaded. Open circles and crosses in eigencoefficients of EOF1 indicate the subperiods with the ten largest and smallest values referenced in the text.

\section{b. Surface air temperature}

E1 (Z500) has a good correspondence with wintertime temperature in Japan. A composite is taken for 10 subperiods when $\mathrm{Cl}(\mathrm{Z500})$ is large (indicated by open circles in Fig. 7 (top)) and small (crosses in Fig. 7 (top)). A composite for surface air temperature (Ts) is shown in Fig. 8. This pattern is very similar to E2 (Ts), which is shown in Fig. 9 together with E1 (Ts). E1 (Ts) explains $17.6 \%$ of the total variance. Its variance is almost confined in high latitudes in the northern hemisphere north of $50^{\circ} \mathrm{N}$. E2 (Ts) explains $15.4 \%$ of the total variance and is characterized by a large temperature contrast between East Asia and the Sea of Okhotsk. A composited mean surface air temperature anomaly map of 10 subperiods when Ts over Japan is warm (not shown) is almost identical to Fig. 8 (top).

The correlation coefficient between $\mathrm{Cl}$ (Z500) and C2 (Ts) is 0.83 . This high correlation is because the mid-latitude circulation response is quasi-barotropic and the anomalous warm surface air temperature in East Asia is mainly caused by anomalous warm advection by southerly winds or a weakened cold surge at the western edge of high pressure anomalies over the North Pacific Ocean. Therefore in the present experiment Japan experiences a warm (cold)
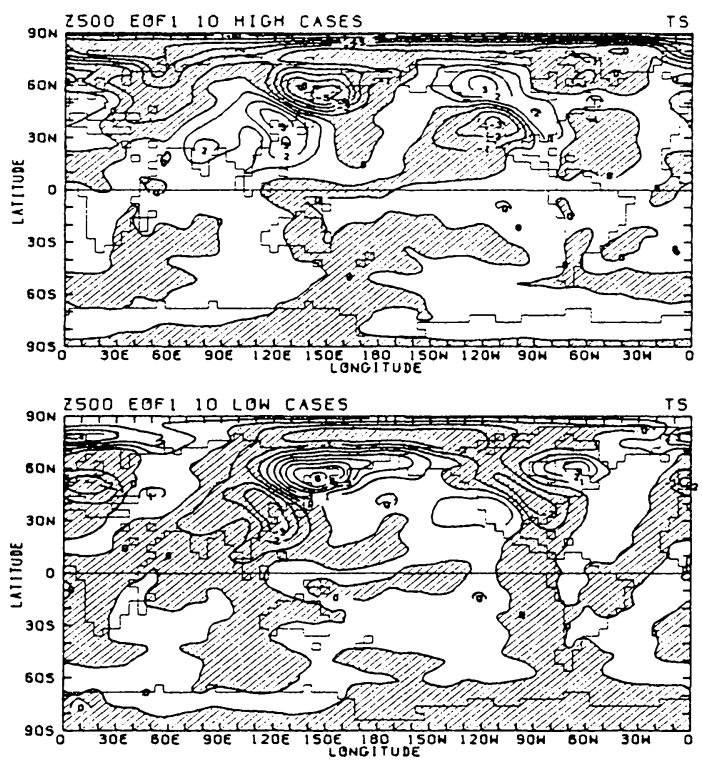

Fig. 8. The surface air temperature anomaly composited for 10 subperiods when $\mathrm{C} 1$ (Z500) is large (top) and small (bottom). Contour interval is $1.0^{\circ} \mathrm{C}$. Negative values are shaded. 

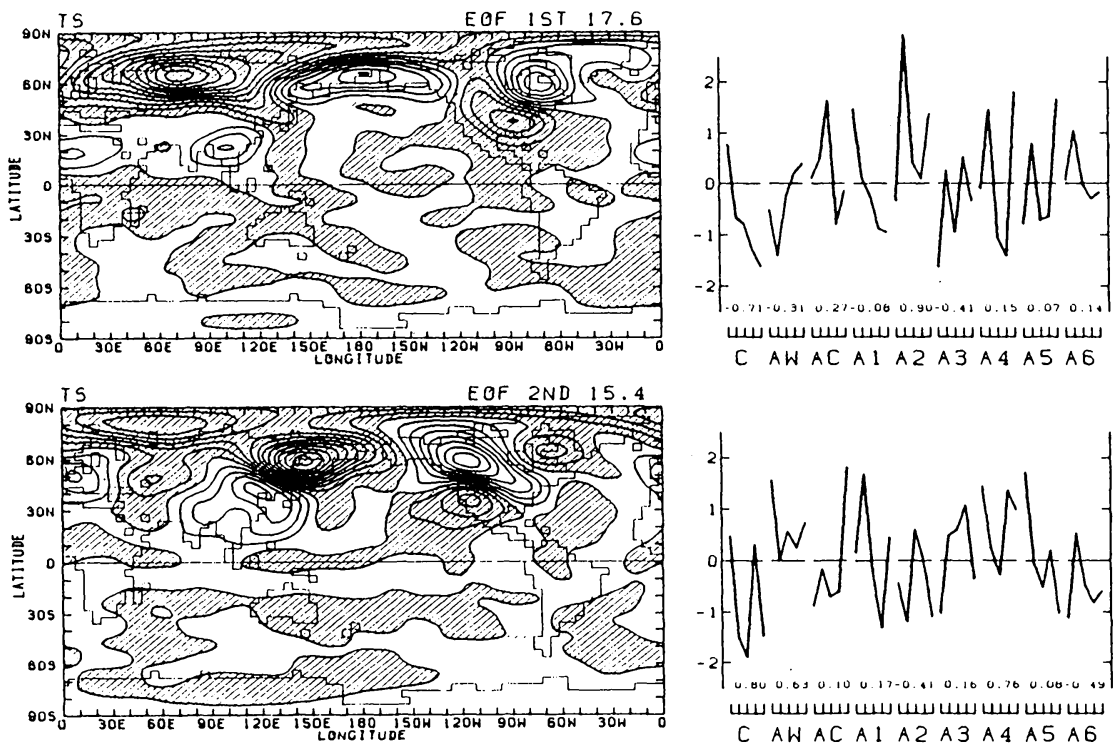

Fig. 9. As in Fig. 7 except for the surface air temperature.

winter when $\mathrm{C} 1$ (Z500) is positive (negative). From Fig. 7, AW, where the SSTA observed during warm winter in Japan are prescribed, results in the warmest temperature in Japan.

In six runs $A 1$ through $A 6$, a characteristic SSTA from the composited SSTA distribution during warm winter in Japan is selected and occurs in six different regions. Among them, run A4, where a positive SSTA occurs to the south of Japan, gives the second largest $\mathrm{Cl}$ (Z500) and the largest $\mathrm{C} 2$ (Ts), resulting in a warm winter in Japan comparable to AW and the corresponding circulation anomalies.

The coldest winter in Japan is simulated in $\mathrm{AC}$, where the characteristic SSTA of cold winter in Japan occurs. On the other hand, it is run $\mathrm{C}$ without any SSTA that has the minimum $\mathrm{C} 1$ (Z500) and the minimum $\mathrm{C} 2$ (Ts).

\section{c. Comparison with the observation}

We shall compare our results with observations. Figure 10 shows the 150-day mean sea level pressure anomalies in $\mathrm{AW}$ and $\mathrm{AC}$ from the mean of all nine cases $(\mathrm{N})$. In this paper, a mid-latitude circulation anomaly relevant to a warm winter in Japan is sought as an intrinsic mode of the atmosphere. Introduction of an EOF analysis is made on this standpoint. The "normal" climate should be an ensemble mean of many realizations obtained by using different SSTs, and is not C, which is only one realization obtained by using a normal SST. Thus $\mathrm{N}$ instead of $\mathrm{C}$ is used as a reference of anomalies.

As $\mathrm{C}$ is the case in which $\mathrm{C} 1$ (Z500) is the minimum in nine cases, an anomaly map of $\mathrm{AC}$ relative to $\mathrm{C}$ is very different from that in Fig. 10. In C-N a cyclonic sea level pressure anomaly in the North Pacific Ocean is dominant with -8 $\mathrm{mb}$ in its central part (not shown). The pattern of AW-C is similar to that of AW-N. Also shown are the observed January sea level pressure anomalies in warm and cold winters defined in Section 2 from the 15-year mean. Observed data are provided by the Japan Meteorological Agency but covers only the northern hemisphere with a resolution of $10^{\circ}$ by $10^{\circ}$.

In both warm and cold winters, sea level pressure anomalies are characterized by a hemispheric spatial scale with positive and negative anomalies over the North Pacific Ocean and northern Eurasia. The January sea level pressure anomalies in both the warm and cold winters are reproduced well by experiments $\mathrm{AW}-\mathrm{N}$ and $\mathrm{AC}-\mathrm{N}$, especially in the eastern hemisphere.

Figure 11 shows the 150-day mean surface air temperature anomalies obtained in AW-N and AC-N. Observed anomalies are calculated from 

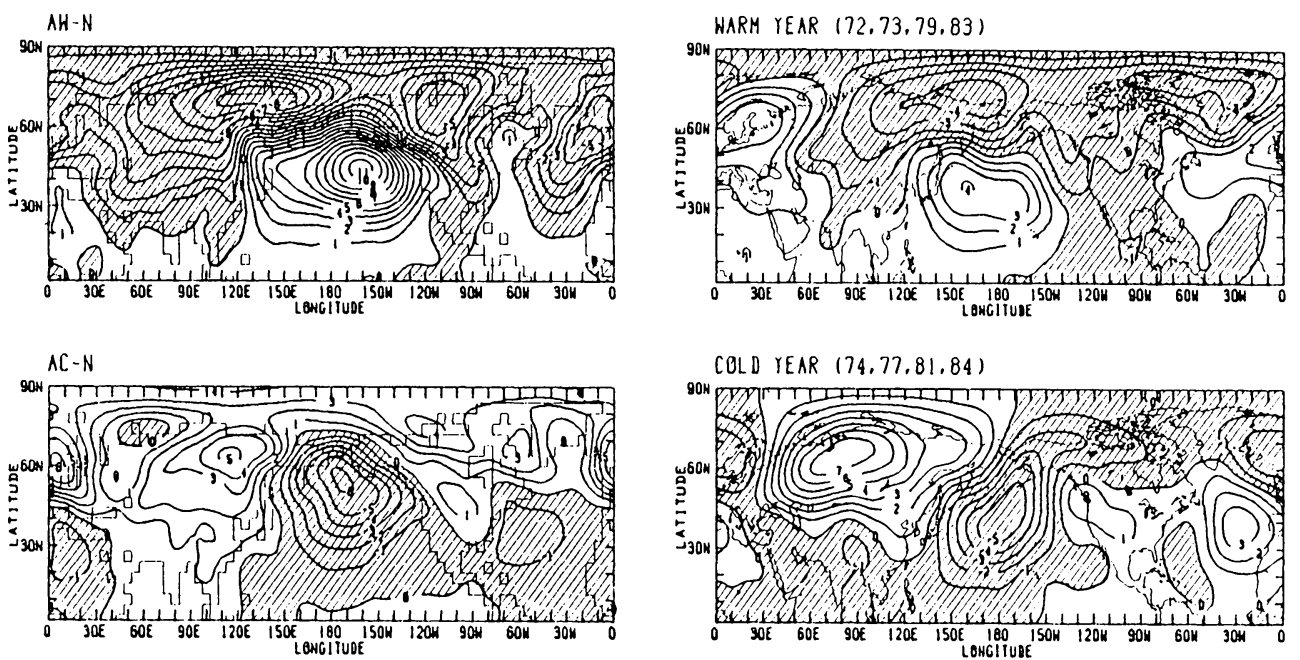

Fig. 10. Comparison with the 150-day mean sea level pressure anomalies for AW and AC from the means of all nine cases and the corresponding observations composited for four warm and cold Januarys in Japan between 1970 and 1984. Contour interval is $1 \mathrm{mb}$. Negative values are shaded.
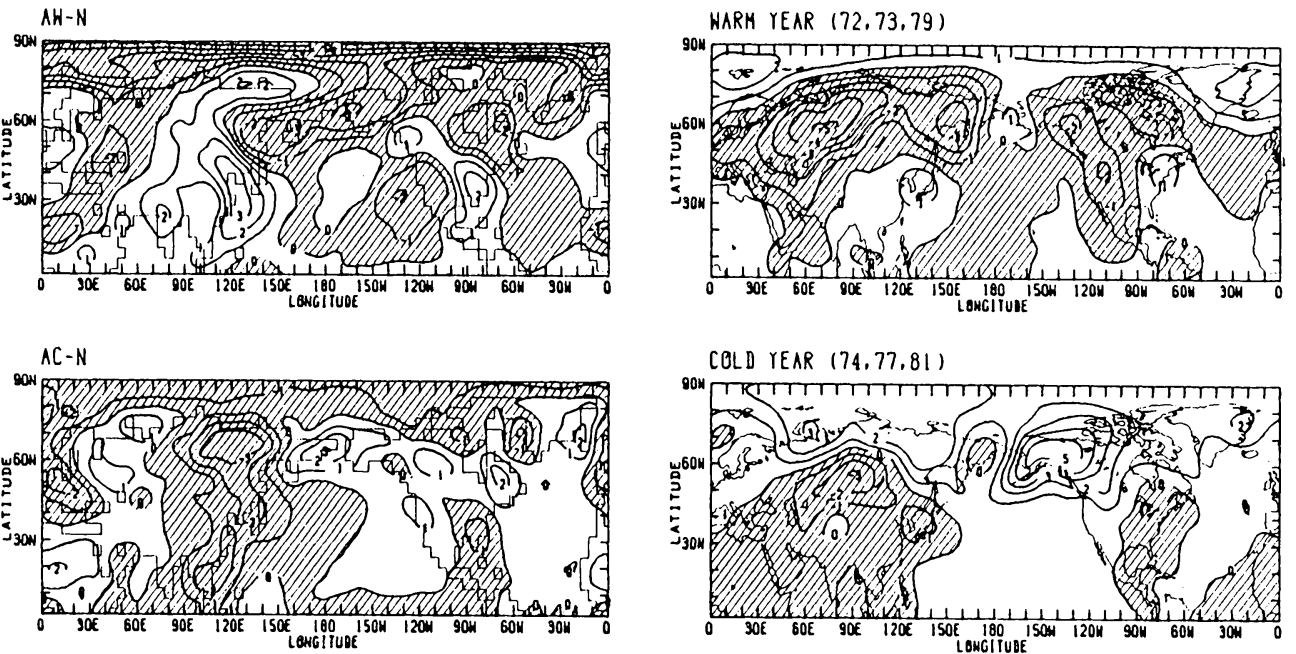

Fig. 11. Comparison with the 150-day mean surface air temperature anomalies for AW and AC from the means of all nine cases and the corresponding observations (Robock, 1982) composited for three warm and cold Januarys in Japan between 1970 and 1981 . Contour interval is $1^{\circ} \mathrm{C}$. Negative values are shaded.

the northern hemisphere surface air temperature anomaly dataset by Robock (1982). This dataset covers the northern hemisphere with a resolution of $5^{\circ}$ in latitude and $10^{\circ}$ in longitude from January 1891 to December 1981 . Therefore, to compose surface air temperature anomalies, January data from 1970 to 1981 are used, where Januarys of 1972, 1973 and 1979 are chosen for the warm years and those of 1974, 1977 and 1981 are chosen for the cold years.
As suggested from a close relationship between E1 (Z500) and E2 (Ts), and a large contribution of E1 (Z500) by AW (Fig. 7), the surface air temperature distribution in AW-N resembles E2 (Ts). It is warm in broad areas in the eastern half of the Eurasian continent with its maximum over the East China Sea. It contrasts well with colder temperature over the Sea of Okhotsk and the Bering Sea. This northeast-southwest contrast of surface air 
temperature with its node around North Japan resembles the observed pattern. This has a close relation with the finding by Miyazaki, Tanaka and Matsubayashi (1986, personal communications) that temperature over Japan tends to be above normal in winters of the mature phase of El Niño, but that it is statistically significant only in the Ryukyu islands. These temperature distributions correspond with wind anomalies near the surface.

Another large temperature anomaly in observations can be found in North America. It is warm in the eastern United States and cold in the rest of North America, which is associated with an anomalous trough over Canada and a ridge in the North Atlantic Ocean. These features in and around North America are seen in AW-N.

The surface air temperature anomalies obtained in AC-N are highlighted with the temperature contrast between the western and eastern peripheries of the North Pacific Ocean. Both the Siberian high and the Aleutian low are strong (Fig. 10). These bring cold arctic air into East Siberia and the cold surge over East Asia is strong. In the western part of North America, including Alaska, anomalous southerly winds bring about warm temperature anomalies. These features are in reasonable agreement with the observation. However the observed temperature distribution over northern Eurasia is not simulated and may not be explained solely by the sea surface temperature anomalies.

\section{Discussions}

\section{a. Relationship between precipitation and circulation anomalies}

In the previous section, it is shown that the circulation pattern which affects the winter climate in East Asia has a hemispheric scale and is particularly related with geopotential height anomalies around $40^{\circ} \mathrm{N}$. In this subsection relationships between precipitation and circulation anomalies will be examined.

A composite map for the precipitation anomalies taken for 10 subperiods when $\mathrm{C} 1$ (Z500) is large is shown in Fig. 12. The spatial pattern of this mode is characterized by positive precipitation anomalies over a narrow belt on the equator over the western Pacific Ocean westward

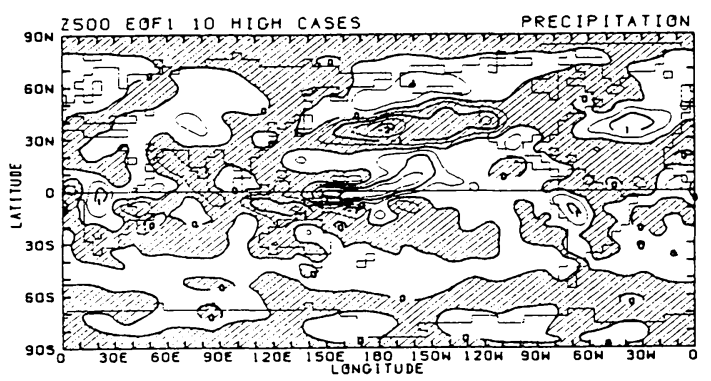

Fig. 12. As in Fig. 8 (top) except for the precipitation. Contour interval is $0.5 \mathrm{~mm} \mathrm{~d}^{-1}$. Negative values are shaded.

of the dateline and around Hawaii, and negative ones between Indonesia and Australia and the North Pacific Ocean with a center around $40^{\circ} \mathrm{N}$. Anomalous precipitation distribution in low latitudes resembles that found in $\mathrm{El}(\mathrm{Pr})$ shown in Fig. 6. The correlation coefficient between $\mathrm{C} 1$ ( $\mathrm{Pr})$ and $\mathrm{C} 1(\mathrm{Z} 500)$ is 0.53 , but eight out of 10 cases with large $\mathrm{C} 1$ (Z500) have also large $\mathrm{C} 1$ (Pr) (see Figs. 6 and 7). Figure 12 indicates that the low-latitude precipitation pattern extracted from the EOF analysis has a close relationship with the mid-latitude circulation pattern, which strongly affects the surface temperature distribution in East Asia.

It is also indicated from Figs. 6 and 7 that a large portion of the total variance in $\mathrm{E} 1(\mathrm{Pr})$ and E1 (Z500) comes from run AW. However, even if five subperiods for AW are removed from compositing Figs. 8 and 12, the results (not shown) do not change much, only reducing the magnitude of a pair of strong precipitation anomalies between the maritime continent and northeast of New Guinea. In the composite map without $\mathrm{AW}$, there are still positive precipitation anomalies over northeast of New Guinea on the equator and over a large part in the central Pacific Ocean between the equator and $20^{\circ} \mathrm{N}$ with its maximum south of Hawaii and a broad negative precipitation anomaly area in the central North Pacific Ocean.

Figure 13 shows the correlation coefficient map between grid values of precipitation anomalies in 45 subperiods and $\mathrm{Cl}$ (Z500). Regions with high correlation are found over the North Pacific Ocean. The precipitation anomaly south of Hawaii $\left(155^{\circ} \mathrm{W}, 14^{\circ} \mathrm{N}\right)$ is highly 


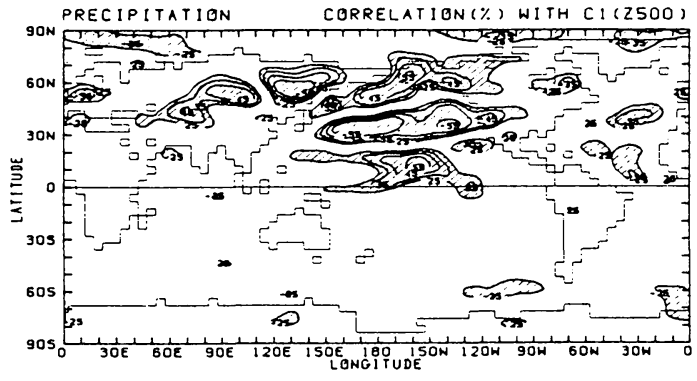

Fig. 13. Correlation map between precipitation and $\mathrm{C} 1$ (Z500) based on the 30-day mean values. Values larger than $25 \%$ are drawn with contour interval of $10 \%$.

correlated with $\mathrm{C} 1$ (Z500). The moisture which is required for this precipitation anomaly comes from the southwest. A moisture budget analysis reveals that the weakened westerlies due to high pressure anomalies are responsible for the negative evaporation anomalies over the North Pacific Ocean around $40^{\circ} \mathrm{N}$, which cause the negative precipitation anomalies there. The positive precipitation anomalies over Alaska are due to the anomalous westerly moisture flux and its convergence from the Bering Sea and the Sea of Okhotsk. Thus, the precipitation anomalies in northern mid-latitudes have been closely tied to mid-latitude circulation changes.

\section{b. Additional run}

Since it is shown that the heating anomaly around the dateline near the equator correlates well with the mid-latitude circulation pattern which mostly affects the climate in East Asia, an additional run was performed to test this relationship. This run, A7, used a positive SSTA to the east of the dateline on the equator, i.e., $180^{\circ}-155^{\circ} \mathrm{W}, 6^{\circ} \mathrm{S}-6^{\circ} \mathrm{N}$ (see Fig. 3), with the maximum of $1^{\circ} \mathrm{C}$ in the central part of this anomaly region.

The top panel of Fig. 14 shows the result, A7-N, for precipitation. There is a large positive anomaly over the SSTA region at the equator. A large asymmetry with respect to the equator exists. Positive anomalies extend northeastward and join a positive anomaly belt at $20^{\circ} \mathrm{N}$. This contrasts with large negative anomalies east of New Guinea at $10^{\circ} \mathrm{S}$. Thus, the precipitation anomaly map obtained in A7-N is similar to Fig. 12. A sea level pressure anomaly map (Fig. 14,
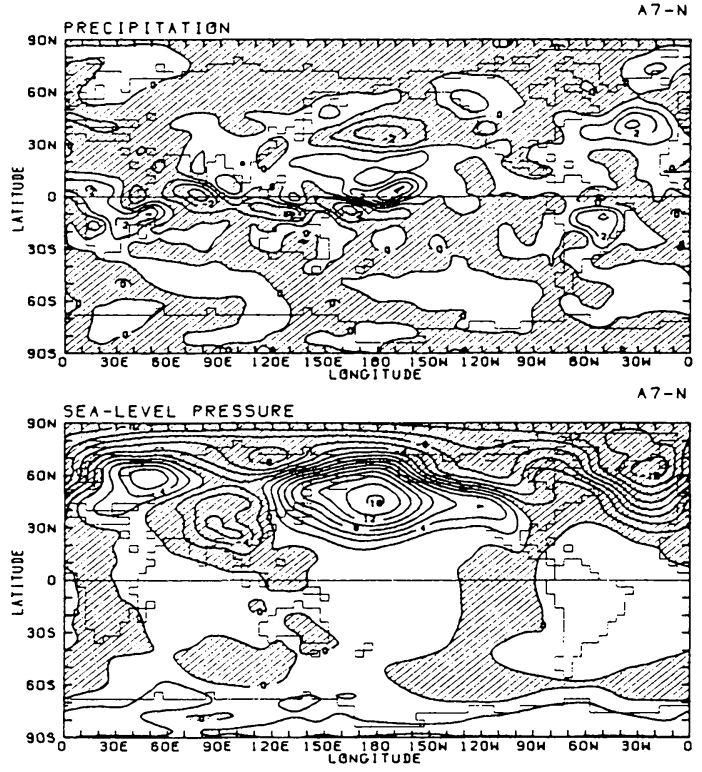

Fig. 14. The 150-day mean anomalies (A7-N) for precipitation (top) and sea level pressure (bottom). Contour intervals are $1 \mathrm{~mm} \mathrm{~d}^{-1}$ and $2 \mathrm{mb}$, respectively. Negative values are shaded.

bottom) shows strong high pressure anomalies over the entire North Pacific Ocean, which have a quasi-barotropic structure. Run A7 also shows warm surface air temperature anomalies over East Asia with its center in South China (not shown). It is noteworthy that the sea level pressure response in A7 is much stronger than in any other run. This again suggests the preference of the positive SSTA near the dateline on the equator, which creates heating anomalies between $180^{\circ} \mathrm{E}, 0^{\circ} \mathrm{N}$ and Hawaii, for producing anticyclonic mid-latitude circulation anomalies. This SSTA region is included in the NINO4 region, $160^{\circ} \mathrm{E}-150^{\circ} \mathrm{W}, 5^{\circ} \mathrm{S}-5^{\circ} \mathrm{N}$, defined by the Climate Analysis Center of NMC.

\section{c. Interpretation of mid-latitude response}

A steady-state atmospheric response to an equatorial forcing is studied by Matsuno (1966), Gill (1980), Lau and Lim (1982), Lim and Chang (1983) and Heckley and Gill (1984). It is shown that for an isolated heat source over the equator, the Kelvin and the gravest Rossby modes dominate in the tropics. However, our present results are not simply explained by this scenario. The stationary stream function and velocity 
a

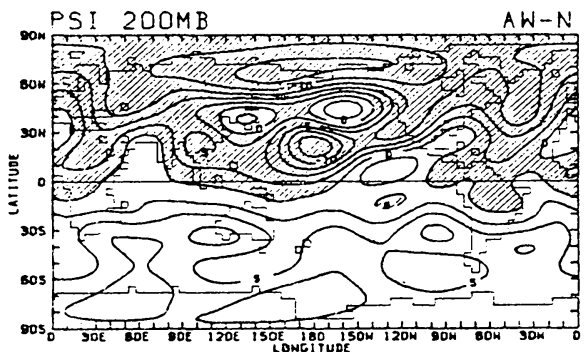

b

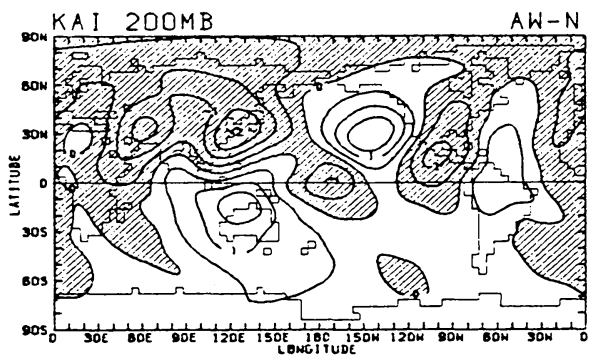

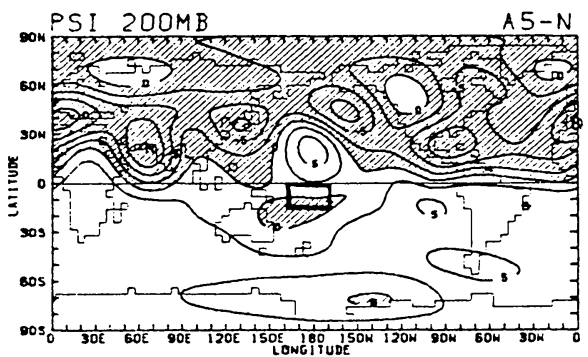
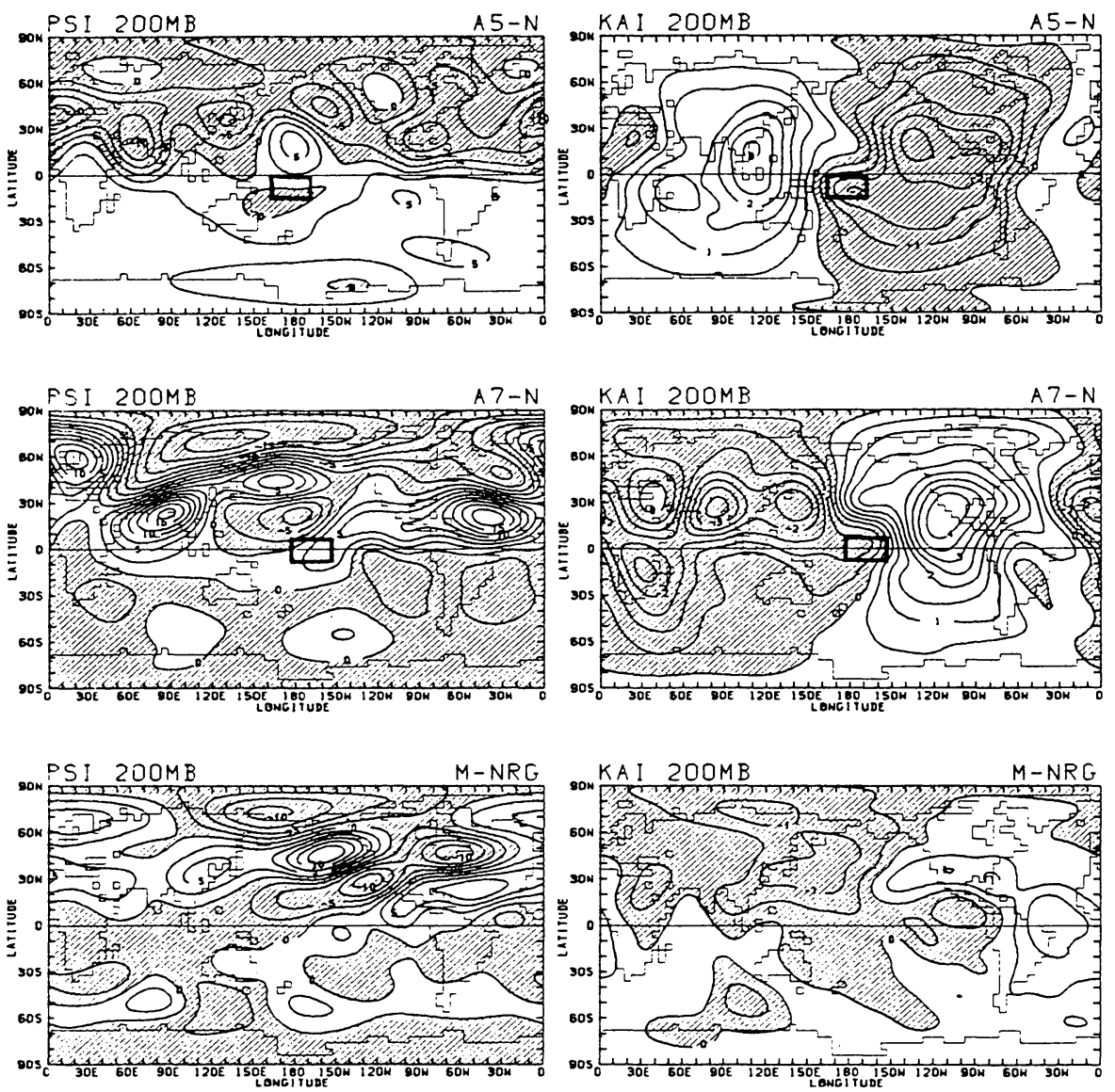

Fig. 15. (a) The 150-day mean stream function anomalies at $200 \mathrm{mb}$ for AW-N, A5-N and A7-N. The bottom panel shows the stream function response at $200 \mathrm{mb}$ to the Rockies plus Greenland forcing in M-NRG (Tokioka and Noda, 1986). Contour interval is $2.5 \times 10^{6} \mathrm{~m}^{2} \mathrm{~s}^{-1}$. Negative values (cyclonic circulation in the Northern Hemisphere) are shaded. Rectangles in A5-N and A7-N represent the areas where the SSTAs are imposed. (b) As in (a) except for the velocity potential at $200 \mathrm{mb}$. Contour interval is $0.5 \times 10^{6} \mathrm{~m}^{2} \mathrm{~s}^{-1}$. 
potential anomalies at $200 \mathrm{mb}$ in AW-N, A5-N and A7-N are shown in Fig. 15. Deep anomalous heating in AW exists around the dateline on the equator (Fig. 5). The stream function anomaly at $200 \mathrm{mb}$ in $\mathrm{AW}$ is characterized by a cyclonic circulation to the north of the heating maximum. This is not attained directly by any equatorial forcing or a linear superposition of them. However, in A5 a different circulation pattern is found, which is similar to a heat induced tropical circulation. In this case anticyclones at $200 \mathrm{mb}$ are found at the longitudes of the heating, not to the west of the heating, in both hemispheres. Hendon (1986) shows that this eastward shift of anticyclones from the position predicted by a linear theory results from the nonlinear response due to the larger forcing. A PNA (Pacific/North America)-like pattern, starting from an anticyclonic circulation west of Hawaii, covers the North Pacific Ocean and North America.

It is noteworthy that the response in $\mathrm{A} 7$ is closer to that in AW than that in A5. This indicates that although the SSTAs in A5 and A7 are similar in magnitude and are close in their positions, the atmospheric response is quite different, implying a high sensitivity of it to the precise position of the SSTA. Atmospheric responses obtained in some GCM studies (e.g., Blackmon et al., 1983; Geisler et al ., 1985) which used a large El Niño SST such as that in $1982 / 83$ winter rather resemble those obtained in A5. Tokioka et al. (1986a) found different atmospheric responses to the composited SSTA by Rasmusson and Carpenter (1982) when they used the whole SSTA as compared to the SSTA westward of $140^{\circ} \mathrm{E}$ eliminated. The latter case produced a PNA-like pattern, somewhat similar to that in A5. It should be stressed that the SSTA distribution in AW is not quite the same as the El Niño composite of Rasmusson and Carpenter (1982), again implying a high sensitivity of the atmospheric response to the characteristics of the SSTA.

A surprisingly similar atmospheric response to that in AW has been obtained in an orography experiment by Tokioka and Noda (1986). They have compared the stationary eddy response, under the perpetual January mode, of the atmosphere without mountains in North America and Greenland (NRG) with that in the control run (M). The difference in stream function and velocity potential at $200 \mathrm{mb}$, M-NRG, is shown in the bottom panel of Fig. 15. The similarity between this and AW-N or E1 (Z500) in the northern hemisphere is noted. The vertically integrated diabatic heating anomalies in M-NRG (Fig. 2 in Tokioka and Noda, 1986) also resemble Fig. 12 in the present experiment. Note that any anomaly in M-NRG may not be a direct response to orography but a result of nonlinear interaction among orographic forcing, diabatic heating and transient eddy forcing. It may be that there is a dominant circulation mode in this model as extracted in El (Z500) and this mode is activated either by an orographic effect of the Rockies through a direct and/or an indirect response, or by an anomalous heating induced by the SSTA. Moreover, this characteristic mode may not be a fabrication of this particular model, as the anomalous circulations obtained in this experiment capture some of the composited observations at least over the North Pacific Ocean and its surroundings (Figs. 10 and 11).

To ascertain the hypothesis that $\mathrm{E} 1 \mathrm{Z}(\mathrm{Z00})$ is an intrinsic mode in the northern mid-latitude atmosphere, the EOFs of $\mathrm{Z} 500$ in three different datasets are compared in Fig. 16. Figure 16a shows the first four eigenvectors (denoted as R1 through R4) obtained for the observed monthly northern hemisphere Z500 in January, February and December in a 41-year period from 1946 to 1986. R1 corresponds to the PNA pattern named by Wallace and Gutzler (1981). R2, R3 and R4 correspond to the eastern Atlantic (EA), the western Atlantic (WA) and the western Pacific (WP) patterns, respectively.

Figure 16b shows the first four eigenvectors (G1 through G4) obtained from a 12-year integration of the MRI-GCM-I (Tokioka et al., 1986b). The integration is performed with the prescribed SST, which changes seasonally but has no year-to-year variation. G1, G2, G3 and G4 correspond to R2, R3, R1 and R4, respectively. The pattern correlation coefficient between $\mathrm{G} 1$ and $\mathrm{R} 2$, PCC $(\mathrm{G} 1, \mathrm{R} 2)$, calculated in a region between $20^{\circ} \mathrm{N}$ and $80^{\circ} \mathrm{N}$ is -0.76 , and PCC $(\mathrm{G} 2, \mathrm{R} 3)$ is -0.50 , PCC $(\mathrm{G} 3, \mathrm{R} 1)$ is 0.58 and PCC $(\mathrm{G} 4, \mathrm{R} 4)$ is 0.68 . The model reproduces the 
a
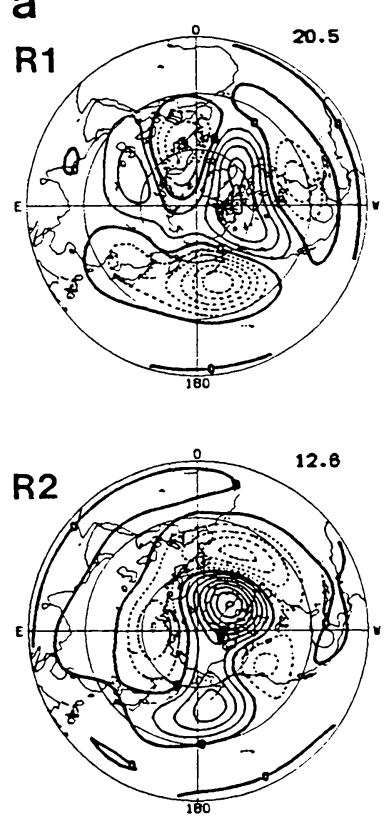

R3

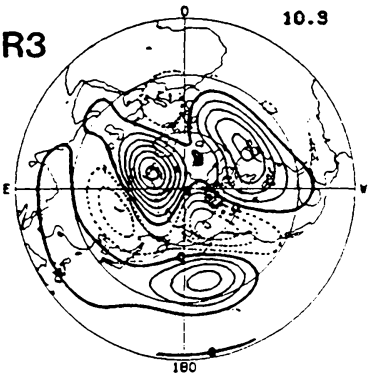

R4

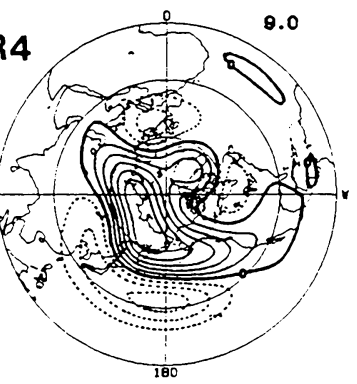

b
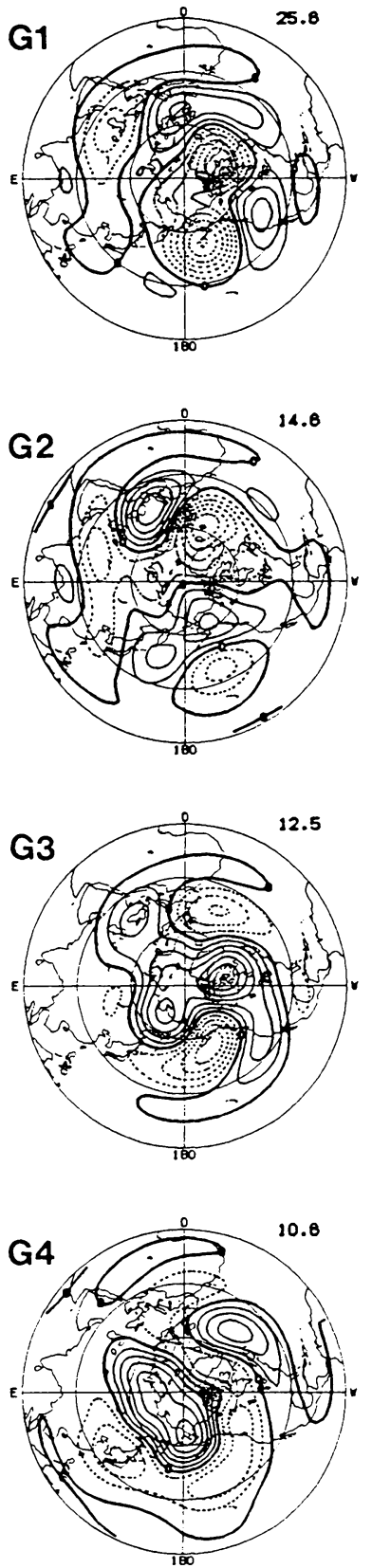
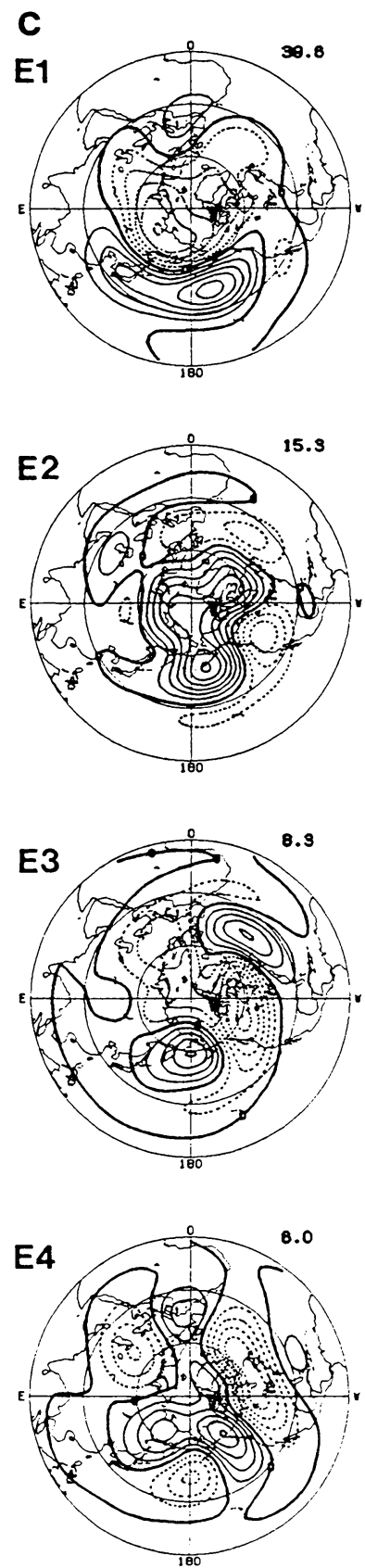

Fig. 16. The first four eigenvectors for geopotential height at $500 \mathrm{mb}$ in the Northern Hemisphere.(a) Observations. Monthly means for January, February and December in 41 years from 1946 to 1986 are used. $\mathrm{n}$ (sample size) $=123$. (b) 12-year run of the MRI-GCM-I (Tokioka et al., 1986b). Monthly means for December, January and February are used. $n=36$. (c) The present experiment. Same as in Fig. 7 except that only the northern hemisphere data are used. $n=45$. 
observed low-frequency variability patterns reasonably. The difference is that the PNA is weaker in the model than in the observation. Considering that no year-to-year variation of the SST is allowed in the model, the observed PNA mode seems to be highly influenced by a variable SST such as El Niño. Further comparison of the low-frequency variability of the atmosphere between the observation and the 12-year run will be the subject of a future paper.

Figure 16c shows El through E4 obtained in this experiment. PCC $(\mathrm{E} 1, \mathrm{G} 4)$ is -0.73 and PCC $(E 2, G 1)$ is -0.88 . This indicates that the northern mid-latitude atmosphere has an intrinsic variation pattern such as E1 (Z500), which is closely related with warm winter in Japan, in this model and also in the observation. Resemblance of this mode to M-NRG suggests that this intrinsic mode is closely related with the existence of orography. Moreover, the fact that this mode is obtained as the first eigenvector in this experiment implies the positive role of the SSTA in increasing the variability of this mode.

It is already shown that the response in A5 can be understood as a circulation induced by an anomalous heating due to the SSTA. However the response in $\mathbf{A} 7$ or $\mathrm{AW}$ is quite different from that in A5 (Fig. 15). The pattern in A7 or AW can be understood as a response to subtropical mass source/sink distribution under the framework of a linear theory. To show this, the linearized shallow-water equation model by Grose and Hoskins (1979) is used.

It is shown in Fig. 15 that in AW and A7, the convergence in the upper troposphere in the eastern Pacific Ocean around $30^{\circ} \mathrm{N}$ forms a pair with the divergence in East Asia. They are very different from the anomalous divergent circulation in A5. Figure 17 shows a steady stream function response to a mass source at $140^{\circ} \mathrm{E}$, $30^{\circ} \mathrm{N}$ and a mass sink at $140^{\circ} \mathrm{W}, 30^{\circ} \mathrm{N}$ with the same magnitude calculated by the use of the linear shallow-water model. The zonally averaged zonal wind at $200 \mathrm{mb}$ in $\mathrm{C}$ is used as a basic field and the shape of the forcing is circular with a radius of $10^{\circ}$. The orography is not considered. Other details are the same as in Grose and Hoskins (1979). This map picks up some of the salient features appearing in AW-N in the North

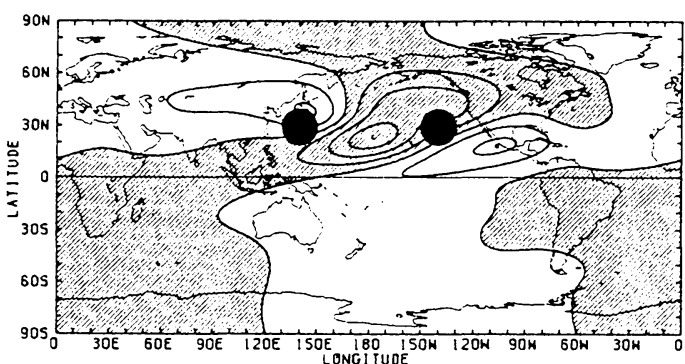

Fig. 17. A steady stream function response in the linear shallow-water model forced by mass source at $140^{\circ} \mathrm{E}, 30^{\circ} \mathrm{N}$ and mass sink at $140^{\circ} \mathrm{W}, 30^{\circ} \mathrm{N}$ (black circles). The zonally averaged zonal wind at $200 \mathrm{mb}$ for $\mathrm{C}$ is used. Contour interval is arbitrary. Negative values are shaded.

Pacific Ocean. On the other hand, the mass source around the dateline at the equator yields a subtropical anticyclone pair and an extratropical wave train like that found in A5-N.

Held and Kang (1987) showed that subtropical divergence anomalies are of more importance than tropical anomalies in generating the extratropical wave train in a barotropic model because the divergence term becomes dominant in extratropics in vorticity generation. The reason for generating such an mass source/sink distribution should be sought in future research. There are some possibilities, including a possible role of a tropically forced Rossby wave in creating the subtropical divergence anomaly as suggested by Held and Kang (1987), as well as the interactions between the tropical forcings and a subtropical jet (Lau and Boyle, 1987), or the zonally averaged zonal wind (Kang and Lau, 1986). In the present experiment the prescribed SSTA to the south of Japan (run A4) results in large $C 1$ (Z500), bringing less cold surge there. This suggests the possibility of directly creating a subtropical mass source or sink by mid-latitude SSTAs. As to the relationship between midlatitude SSTAs and circulation anomalies, Kawamura (1984, 1986) and Iwasaka et al. (1987) show by lag-correlation analysis that the SSTA near Japan is highly correlated with the mid-latitude circulation one-month before in winter. The present experiment suggests that the warm SST over the western Pacific Ocean is not only modulated by thermal forcing (cold surge) of the atmosphere, but also may contribute to 
forming such a circulation to some extent.

\section{Conclusions}

One control (C) and nine anomaly runs (AW, $\mathrm{AC}, \mathrm{A} 1, \ldots \mathrm{A} 7)$ under the perpetual January condition are performed to investigate the impact of sea surface temperature anomalies on atmospheric circulations with emphasis on the winter climate in Japan.

Run AW (AC) uses the composited SSTA of 1972, 1973, 1979 and 1983 (1974, 1977, 1981 and 1984) when Japan experienced warm (cold) winters between 1970 and 1984. Runs A1 through A6 use an idealized rectangular SSTA with its maximum of $1^{\circ} \mathrm{C}$, which is positive over the south maritime continent, the north maritime continent, the Indian Ocean, south of Japan, the central equatorial Pacific Ocean and negative east of the Philippines, respectively. An additional run $\mathbf{A} 7$ specifies a positive SSTA over the equator to the east of the dateline. Each run has been integrated for 180 days and the last 150 days' data are used for the analysis.

The EOF analyses based on the 30-day average model data for $500 \mathrm{mb}$ height, surface air temperature and precipitation are performed. It is shown that leading eigenvectors of precipitation are zonally elongated in the tropics and the distribution of a pair of positive and negative precipitation anomalies is highly dependent on the SST and precipitation field in the control run.

E1 (Z500) has a tendency to appear simultaneously with E2 (Ts). These eigenvectors are associated with a height anomaly over the North Pacific Ocean and warm temperature over China-Japan region and cold temperature over the Sea of Okhotsk. Run AW has the highest scores of $\mathrm{Cl}$ (Z500), resulting in the warmest Japan in the experiment. A4 (warm SSTA to the south of Japan) follows AW, in which the cold surge from Siberia is weak over China and Japan. On the other hand, run $\mathrm{C}$ (control experiment without any SSTA), A6 (cold SSTA to the east of the Philippines) and AC show the three small C1 (Z500). The simulated anomalies in midlatitude circulation and surface air temperature for $\mathrm{AW}$ and $\mathrm{AC}$ are comparable to the composited observations in the North Pacific
Ocean and its surroundings, suggesting the importance of the SSTAs as boundary forcings.

There is a high correlation between $\mathrm{C} 1 \mathrm{Pr}$ ) and $\mathrm{C} 1$ (Z500). The spatial pattern of this precipitation mode is characterized by positive anomalies over a narrow belt on the equator over the western Pacific Ocean westward of the dateline and to the south of Hawaii, and has negative ones between Indonesia and Australia, and over the North Pacific Ocean with its center at $40^{\circ} \mathrm{N}$. It is indicated that a heating anomaly south of Hawaii is highly correlated with $\mathrm{C} 1$ (Z500). It is also suggested by an additional run that the SSTA just to the east of the dateline on the equator is effective in producing such a heating and circulation anomaly.

The response obtained in $\mathrm{AW}$ is not a simple atmospheric response to tropical heating. It is conceivable that there is inherently a dominant circulation mode like E1 (Z500) and that this mode can be activated either by a direct and/or an indirect orographic effect, or by an anomalous heating induced by the SSTA. This pattern can be understood as a response to subtropical mass source/sink distribution under the framework of a linear theory.

\section{Acknowledgments}

The author is grateful to Dr. T. Tokioka of MRI for his initial guidance, continuous encouragements and discussions throughout this work. He thanks Messrs. M. Ohzeki and Y. Tsuyuki of JMA for kindly providing him a program of the linearized shallow-water equation model. Thanks are extended to Dr. K. Yamazaki of MRI for discussions and two reviewers for comments to the original manuscript.

Computations are made with HITAC S810 at MRI.

\section{References}

Arakawa, A. and W.H. Schubert, 1974: Interaction of a cumulus cloud ensemble with the large-scale environment. Part I. J. Atmos. Sci., 31, 674-701.

Bjerknes, J., 1966: A possible response of the atmospheric Hadley circulation to equatorial anomalies of ocean temperature. Tellus, 18, 820-829.

, 1969: Atmospheric teleconnections from the equatorial Pacific. Mon. Wea. Rev., 97, 163-172. 
Blackmon, M.L., J.E. Geisler and E.J. Pitcher, 1983: A general circulation model study of January climate anomaly patterns associated with interannual variation of equatorial Pacific sea surface temperatures. $J$. Atmos. Sci, 40, 1410-1425.

Branstator, G., 1985: Analysis of general circulation model sea-surface temperature anomaly simulation using a linear model. Part I: Forced solution. $J$. Atmos. Sci., 42, 2225-2241.

Cornejo-Garrido, A.G. and P.H. Stone, 1977: On the heat balance of the Walker circulation. J. Atmos. Sci., 34, 1155-1162.

Deardorff, J.W., 1972: Parameterization of the planetary boundary layer for use in general circulation models. Mon. Wea. Rev., 100, 93-106.

Frankignoul, C., 1985: Sea surface temperature anomalies, planetary waves, and air-sea feedback in the middle latitudes. Rev. Geophys., 23, 357-390.

Geisler, J.E., M.L. Blackmon, G.T. Bates and S. Munoz, 1985: Sensitivity of January climate response to the magnitude and position of equatorial sea surface temperature anomalies. J. Atmos. Sci., 42, 1037-1049.

Gill, A.E., 1980: Some simple solution for heat-induced tropical circulation. Quart. J. R. Met. Soc., 106, 447-462.

Grose, W.L. and B.J. Hoskins, 1979: On the influence of orography on large-scale atmospheric flow. J. Atmos. Sci., 36, 223-234.

Heckley, W.A. and A.E. Gill, 1984: Some simple analytical solutions to the problem of forced equatorial long waves. Quart. J. R. Met. Soc.., 110, 203-217.

Held, I.M. and I.-S. Kang, 1987: Barotropic models of the extratropical response to El Niño. J. Atmos. Sci., 44, 3576-3586.

Hendon, H.H., 1986: The time-mean flow and variability in a nonlinear model of the atmosphere with tropical diabatic forcing. J. Atmos. Sci. 43, $72-88$.

Horel, J.D. and J.M. Wallace, 1981: Planetary-scale atmospheric phenomena associated with the Southern Oscillation. Mon. Wea. Rev., 109, 813-829.

Iwasaka, N., K. Hanawa and Y. Toba, 1987: Analysis of SST anomalies in the North Pacific and their relation to $500 \mathrm{mb}$ height anomalies over the Northern Hemisphere. J. Meteor. Soc. Japan. 65, 103-114.

Japan Meteorological Agency, 1980: Climatological Observations for 1971-1975. Technical Data Series, No. 44, 73 pp.

- 1981: Climatological Observations for 1967-1970. Technical Data Series, No. 45, 74 pp.

- 1984: Climatological Observations for 1976-1980. Technical Data Series, No. 48, 74 pp.

, 1987: Climatological Observations for 1981-1985. Technical Data Series, No. 52, 76 pp.

Julian, P.R. and R.M. Chervin, 1978: A study of the Southern Oscillation and Walker circulation phenomenon. Mon. Wea. Rev., 106, 1433-1451.
Kang, I.-S. and N.-C. Lau, 1986: Principal modes of atmospheric variability in model atmospheres with and without anomalous sea surface temperature forcing in the tropical Pacific. J. Atmos. Sci, 43, 2719-2735.

Katayama, A., 1972: A simplified scheme for computing radiative transfer in the troposphere. Tech. Report No. 6, Department of Meteorological, University of California, Los Angeles, CA, 77 pp.

- 1978: Parameterization of planetary boundary layer in atmospheric general circulation models. Kisyo Kenkyu Note, Meteor. Soc. Japan, No. 134, 153-200. (in Japanese)

Kawamura, R., 1984: Relation between atmospheric circulation and dominant sea surface temperature anomaly pattern in the North Pacific during the northern winter. J. Meteor. Soc. Japan, 62, 910-916. , 1986: Seasonal dependency of atmosphereocean interaction over the North Pacific. J. Meteor. Soc. Japan, 64, 363-371.

Keshavamurty, R.N., 1982: Reponse of the atmosphere to sea surface temperature anomalies over the equatorial Pacific and the teleconnections of the Southern Oscillation. J. Atmos. Sci, 39, 1241-1259.

Lau, K.M. and H. Lim, 1982: Thermally driven motions in an equatorial $\beta$-plane: Hadley and Walker circulation during the winter monsoon. Mon. Wea. Rev., 110, 336-353.

and P.H. Chan, 1983a: Short-term climate variability and atmospheric teleconnection as inferred from satellite-derived outgoing longwave radiation. I: Simultaneous relationships. J. Atmos. Sci. 40, 2735-2750. and

1983b: Short-term climate variability and atmospheric teleconnection as inferred from satellite-derived outgoing longwave radiation. II: Lagged correlation. J. Atmos. Sci., 40, 2751-2767.

and J.S. Boyle, 1987: Tropical and extratropical forcing of the large-scale circulation: A diagnostic study. Mon. Wea. Rev., 115, 400-428.

Lim, H. and C.-P. Chang, 1983: Dynamics of teleconnections and Walker circulations forced by equatorial heating. J. Atmos. Sci., 40, 1897-1915.

Matsuno, T., 1966: Quasi-geostrophic motions in the equatorial area. J. Meteor. Soc. Japan, 44, 25-43.

Mechoso, C.R., A. Kitoh, S. Moorthi and A. Arakawa, 1987: Numerical simulations of the atmospheric response to a sea surface temperature anomaly over the equatorial eastern Pacific Ocean. Mon. Wea. Rev., 115, 2936-2956.

Nihoul, L.C.J., 1985: Coupled Ocean-Atmosphere Models. Elsevier Science Publishers, Amsterdam.

Rasmusson, E. and T. Carpenter, 1982: Variations in tropical sea surface temperature and surface wind fields associated with the Southern Oscillation/El Niño. Mon. Wea. Rev., 110, 354-384.

Robock, A., 1982: The Russian surface temperature dataset. J. Appl. Meteorol., 21, 1781-1785. 
Ropelewski, C.F. and M.S. Halpert, 1987: Global and regional scale precipitation patterns associated with the El Niño/Southern Oscillation. Mon. Wea. Rev., 115, 1606-1626.

Rowntree, P.R., 1972: The influence of tropical east Pacific Ocean temperature on the atmosphere. Quart. J. R. Met. Soc., 98, 290-321.

Schutz, C. and W.L. Gates, 1971: Global climatic data for surface, $800 \mathrm{mb}, 400 \mathrm{mb}$ : January. Advanced Research Projects Agency, Rep. R-915-ARPA, Rand Corporation, Santa Monica, $73 \mathrm{pp}$.

Shukla, J. and J.M. Wallace, 1983: Numerical simulation of the atmospheric response to equatorial Pacific sea surface temperature anomalies. J. Atmos. Sci., 40, 1613-1630.

Simmons, A.J., J.M. Wallace and G.W. Branstator, 1983: Barotropic wave propagation and instability, and atmospheric teleconnection pattern. J. Atmos. Sci., 40, 1363-1392.

Tokioka, T., K. Yamazaki, I. Yagai and A. Kitoh, 1984: A description of the Meteorological Research Institute atmospheric general circulation model (MRI.GCM-I). Technical Report of the Meteorological Research Institute, No. 13, MRI, Tsukuba, 249 pp.

A. Kitoh, I. Yagai and K. Yamazaki, 1985: A simulation of the tropospheric general circulation with the MRI atmospheric general circulation model. Part I: The January performance. J. Meteor. Soc.
Japan, 63, 749-778.

and A. Katayama, 1986a:

Atmospheric response to the sea surface temperature anomalies in the mature phase of E1 Niño: Numerical experiment under the perpetual January condition. J. Meteor. Soc. Japan, 64, 347-362.

K. Yamazaki and A. Kitoh, 1986b: Mean statistics of the tropospheric MRI.GCM-I based on 12-year integration. Technical Report of the Meteorological Research Institute, No. 20, MRI, Tsukuba, $314 \mathrm{pp}$. and A. Noda, 1986: Effects of large-scale orography on January atmospheric circulation: A numerical experiment. J. Meteor. Soc. Japan, 64, 819-840.

van Loon, H. and J.C. Rogers, 1981: The Southern Oscillation. Part II: Associations with changes in the middle troposphere in the northern winter. Mon. Wea. Rev., 109, 1163-1168.

Wallace, J.M. and D.S. Gutzler, 1981: Teleconnections in the geopotential height field during the Northern Hemisphere winter. Mon. Wea. Rev., 109, 784-812.

WCP, 1986: Comparison of Simulations by Numerical Models of the Sensitivity of the Atmospheric Circulation to Sea Surface Temperature Anomalies. NCAR, Boulder, Colo., December 1985. WMO/TDNo. 138 , WCP-121, 188 pp.

Weare, B.C., 1986: Extension of an El Niño index. Mon. Wea. Rev., 114, 644-647.

\title{
海面水温と日本の暖冬に関する数値実験
}

\author{
鬼 頭 昭 雄 \\ (父象研究所父候研究部)
}

日本の暖冬・寒冬に重点を置いて，海面水温偏差の大父に対するインパクトを調べた。5 屏 MRI·GCM-Iを用いて, perpetual January modeで一連の180日間皘分を 9 例行ない，30月壮均降水 量， $500 \mathrm{mb}$ 高度，地表父溫の主成分分析を行なった。

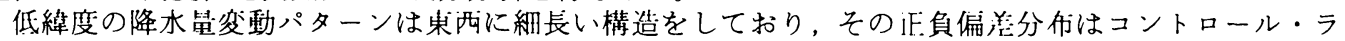
ンの海自水温亚びに降水量分布に依存している。東アジアの地戗父温は，H本から中国にかけての領域 とオホーツク海との対照が特徴であり, これは北太平洋の高気压偏着とシベリアからのコールド・サー

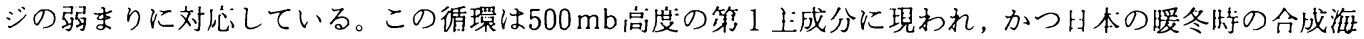
面水温（1972,73,79,83）を肘いたランで卓越している。この時の環太半洋領域の循環物のアノマリーは 観测と刘応している。

この中緯度循環パターンは八ワイの南方の降水虽偏差之音相関があり，これは赤道.

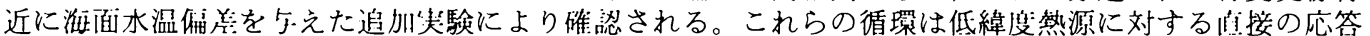
ではない。川本暖冬パターンは大気に闾有のモードであることが示され，海面水温偏差によりこのパ ターンの出垷频度が高くなったと示唆される。線形モデルの範用では，このパターンは型熱带の発散場

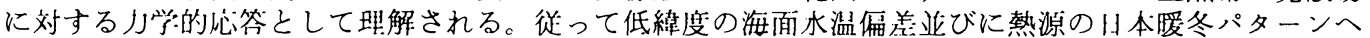
の影響は卢接的なものではなく，业熱带循舆の变動を通じで坚現される間接的なものである。 